arq 24.4 - THEORY - Parnell and Sawyer - AS - Pre-FINAL 27.11.20

Architecture simply wouldn't be architecture without the architectural magazine. Proposing an 'architectural magazine exceptionalism' and a special relationship between architecture and the periodical format.

\title{
In search of architectural magazines
}

\author{
Stephen Parnell and Mark Sawyer
}

This paper develops a theoretical framework for the relationship between the architectural magazine and architecture, understood as a profession, a discipline, and a culture. By developing David Abrahamson's idea of 'magazine exceptionalism' from the field of magazines studies, it offers a definition of what constitutes an architectural magazine, arguing that to be architectural, a magazine must be a site of architectural production, as either a validator in the field of architecture or as an architectural project in its own right.

Developing the concept of 'architectural magazine exceptionalism' through an analysis of the 'architectural journalscape', we reflect on the medium's special relationship with architecture to argue that the architectural magazine is a fundamental component of modern architecture. We identify three sub-genres of architecture magazine, corresponding to architecture's sub-fields - profession, discipline, and culture - and a fourth, hybrid genre intersecting the other three which exemplifies architecture's complexity and contradiction. The paper concludes by extending Beatriz Colomina's claim that 'modern architecture only becomes modern with its engagement with the media', arguing that modern architecture simply would not be architecture without the architectural magazine. This conclusion recommends that the medium itself should be considered a crucial subject for architectural research.

\section{A special relationship}

Architectural magazines have a special relationship with the profession they represent: a relationship that is as unique and complicated and gloriously unpindownable as architecture itself. ${ }^{1}$ In recent years there has been a steady increase in interest in architectural magazines. There have been $\mathrm{PhDs}_{1}{ }^{2}$ conference sessions, ${ }^{3}$ and edited books on individual architecture titles, ${ }^{4}$ as well as on the genre more broadly ${ }^{5}$ 
and it is now widely acknowledged that periodicals have played an important role in the formation of architecture. They are: spaces for polemic and critical writing outside the confines of everyday architectural practice; ${ }^{6}$ sites for avant-garde experimentation that pre-empt 'real world' productions; ${ }^{7}$ and vehicles for the construction and dissemination of architectural theory ${ }^{8}$ and criticism. ${ }^{9}$ The periodical nature of magazines allows an architectural discourse to develop between interlocutors over extended periods in a call-and-response mechanism, ${ }^{10}$ and they are important 'historical sources', ready-made archives for studying how architecture develops as discipline and profession. ${ }^{11}$ Philip Goad claimed that periodicals - in his case Architecture Australia - 'mirror the shifting tastes, passions and practical issues facing a group of professionals' and most importantly, when collected, form 'critical historical documents that depict the development and shaping of a profession' ${ }^{12}$

The largest and most celebrated project on architectural magazines to date is Clip/Stamp/Fold: The Radical Architecture of Little Magazines, 196X - 197X, a series of exhibitions and resulting book by the Media and Modernity group at Princeton University, initiated by Beatriz Colomina in 2004. Clip/Stamp/Fold was a great spectacle but, for all its exhaustive curation, it did not theorise the magazine and offered little in the way of methodology for how to study an architectural magazine or reflection on their nature and relationship with, or position within, the field of architecture. That same year the Canadian Centre for Architecture (CCA) held a colloquium on architectural magazines of the same period, albeit not exclusively 'little' magazines. ${ }^{13}$ Its proceedings included a substantial bibliography of all known work to date on architectural magazines and a thorough introduction to methodologies of studying them as both historical sources and cultural objects in their own right. ${ }^{14}$

Building on such work on architecture periodicals, and introducing ideas from the recently emerged discipline of magazine studies, ${ }^{15}$ this paper aims to define the architectural magazine as a specific entity that plays a fundamental role in the formation - and therefore understanding - of architecture. We argue that there is something special about the printed architectural magazine that is integral to architecture, and that magazines still matter profoundly even as they are displaced to some extent by digital publishing.

\section{An architectural magazine exceptionalism}

Despite recent attempts to define subcategories within architectural magazine publishing - for instance, Véronique Patteuew's delineation of the qualities that make an architectural magazine 'little' at any point in time ${ }^{16}-$ a more fundamental unanswered question remains: what actually is an architectural magazine? What are their characteristics by which they are recognised? How is the medium classified, categorised, and defined? Are magazines distinct from school newsletters, reviews, and other serialised media? How do they relate to scholarly journals? For instance, is Archigram a magazine? Or Oppositions? Both appeared in Clip/Stamp/Fold but both are very different objects with different material qualities, textual forms, 
organisational structures, and reasons for existing. These are far from trivial questions, because, as Marcia Prior-Miller puts it, 'the question of how to define the scope of the medium and what is or is not a magazine or other non-newspaper periodical is core to studying the magazine'. ${ }^{17}$

Over fifty years ago, Marshall McLuhan presciently declared the medium to be the message, claiming that 'a medium isn't something neutral, it does something to people, it takes a hold of them' and that '[s]ocieties have always been shaped more by the nature of the media by which men communicate than by the content of the communication. ${ }^{18}$ With digital technologies, McLuhan's message is more relevant than ever and so this paper aims to examine the medium (rather than its message) of the magazine and what it does to architects and architecture. Architects have not previously reflected on their favourite medium but, fortunately, magazine studies literature can help us to identify what is and is not a magazine and we can use this as the basis of defining our object of study:

- First, and perhaps most obviously, magazines are media texts that are released periodically and that maintain an identity that endures over time. Magazines are related to other periodicals including 'pamphlets, books, leaflets, cards, catalogues, and posters ${ }^{\prime 19}$ within a 'broad range of non-newspaper serials.' ${ }^{20}$ We identify some subcategories of architectural magazines below.

- Second, although magazines contain a great variety of (potentially contradictory) content, ${ }^{21}$ conveyed through a range of semiotic modes that may include combinations of the textual, visual, typographic, kinetic, and more, ${ }^{22}$ Tim Holmes has explained that '[m]agazines are about something, and [...] have to offer value to a specific audience. ${ }^{23}$ While this paper concentrates on the printed magazine, we acknowledge that magazines can exist in a variety of formats, each of which affects the world and its audience differently. They have historically appeared in the form of cassette tapes, ${ }^{24}$ radio or television programmes, and today's versions may be digital only, and might include, for example, the relatively new genre of podcasts.

- Third - and most crucially - magazines are directed towards the interests of a particular group of readers and aim to be read actively in a way that catalyses action. ${ }^{25}$ This intentionally constructivist agenda was identified by David Abrahamson, who usefully proposed the key differences of magazines from other forms of journalistic media through his term 'magazine exceptionalism'. ${ }^{26} \mathrm{He}$ explained that, 'in most cases, the editors and writers of magazines share a direct community of interest with their readers. They are often, indeed literally, the same people'.27 Magazine scholars have turned to the notion of the 'interpretive community' to explain this absence of journalistic distance between magazine producers and consumers, a situation amplified in architectural publishing by the shared techniques in designing publications and buildings which we explore below. ${ }^{28}$ Furthermore, 'in many instances the editorial content of magazines is specifically designed by its editors and looked to by its readers as something that will lead to action. ${ }^{29}$ 
These two factors lead to 'the central claim of magazine exceptionalism: that magazines not only reflect or are a product of the social reality of the times, but they also serve a larger and more pro-active function - that they can also be a catalyst, shaping the very social reality of their sociocultural moment'. ${ }^{\prime 0}$ Magazines therefore, act not only as reflectors, but also directors of a particular field of interest. ${ }^{31}$

Architectural magazines, then, are not only magazines about architecture, but also places where architecture is created. With this in mind, we suggest that there is something distinctive about architectural magazines and a study of their relationship with architecture might reveal insights into the nature of the field and its history for three distinct reasons. First, they are the chief creators of the 'critical sphere' 32 in which architectural discourse - some would say architecture itself - is created. Second, they are primary spaces for the incubation, and vehicles for the transmission, of architectural ideas. And, third, they act as time capsules for architectural knowledge and a subsequent reading of history. In short, they present and represent architecture.

In their introduction to the CCA colloquium's proceedings Hélène Jannière and France Vanlaethem anticipated the sentiment of the term 'magazine exceptionalism' by arguing that the architectural magazine is a 'particular type of publication'.$^{33}$ To try to pin down what this means, we suggest augmenting Abrahamson's original formulation with a further characteristic particular to architectural magazines, namely that they function as architectural projects: 'sites for architectural production', ${ }^{34}$ as Colomina and Buckley noted, or what Parnell has called a 'playground and battleground'.$^{35}$ The three characteristics that form the extended term, 'architectural magazine exceptionalism', then, define the architectural magazine as an object of inquiry. To summarise, architectural magazines:

- have little journalistic distance between producers and readers;

- are simultaneously reflectors and directors of the field of architecture;

- are sites of architectural production in and of themselves.

Architectural magazines exhibit this third characteristic - sites of architectural production - in two ways: first, as validators of architecture; and second, as works of architecture in their own right, which we explore in detail below. This concept of architectural magazine exceptionalism has implications for the discipline, profession, and academic research on architecture, and is why printed magazines still matter in a digital age.

\section{Sites of architectural production}

In The Structural Transformation of the Public Sphere, Jürgen Habermas described how public opinion is constructed through the press. ${ }^{36}$ Richard Wittman has recently adapted this to the eighteenth-century French architectural press, understanding the phrase 'civic public sphere' as constituting:

less [...] a metaphorical space than [...] a network: a network for the circulation of information, ideas, and opinion about any aspect of experience that is, or seems, to be of general interest. It is within and through this network that 
public opinion is formed. It is composed of overlapping space, signs, and discourses. A printed book, a conversation with a stranger in a coffeehouse, a painting on exhibit, or a public building [...] all participate in it, though the media [...] is its most vital component. ${ }^{37}$

Wittmann goes on to demonstrate how the 'literate public thought about architecture' in eighteenth-century France through the medium of publication. ${ }^{38}$

As Habermas' translator points out, the original German term Öffentlichkeit doesn't render easily into English and 'misleadingly spatializes the concept': it also crucially implies the idea of 'publicness' or 'publicity'. ${ }^{39}$ Nevertheless, this idea of a space or network can equally apply to architecture where we might better recognise it as simply 'architectural discourse' ${ }^{40}$ Accepting Habermas' concept, the very idea of architecture, as distinct from building, and as a discourse that ultimately emerged as a self-contained profession, could only happen as a result of this process, at the centre of which has been the publication. The role of the publication has inevitably changed over time, just as Habermas described the rise and fall of the public sphere and its relationship with politics. But it is worth remembering that, since its inception in the early nineteenth century, the architectural magazine has been instrumental central even - to creating a space for the production of architecture. ${ }^{41}$

As its relationship with architecture has evolved, the architectural press enabled the construction of this critical sphere in two interrelated ways: first, as instruments of validation that define what should and shouldn't be considered architecture; and, second, through their status as design objects whose production shares methods and techniques with architectural design practices, and that therefore physically create a medium, or space, whether on screen or on paper, for architectural discourse to occur. While Wittman denies this spatialisation, as architects, we argue that this spatial aspect of the medium should not be considered any less important than a building in which ideas are discussed and debated, whether coffeeshops or town halls.

\section{Instruments of validation}

Several theorists have discussed architecture's construction through publications in different ways to Habermas' critical sphere. Andrew Higgott argued that: the reality of architecture portrayed in professional journals and books does not come unfiltered, but is edited, framed and presented in such a way that it is transformed. It becomes the architecture: the book or journal constructs a reality rather than representing it. ${ }^{42}$

This idea transforms the architectural magazine itself - the physical composition of photographs, drawings, and texts, independent of the critical discourse - into a site of architectural production in its own right and claims the magazine as a work of architecture.

Colomina, who famously claimed that 'modern architecture only becomes modern with its engagement with the media', ${ }^{43}$ came closer to Habermas when she wrote that 'architecture, as distinct from building, is an interpretative, critical act. It 
has a linguistic condition different from the practical one of building'. ${ }^{44}$ Kester Rattenbury shares this view that 'architecture - as distinct from building - is always that which is represented, and particularly that which is represented in the media aimed at architects', ${ }^{45}$ suggesting there is a process of selection or curation in which the press participates, that elects a building to the architectural canon.

Since long before Nikolaus Pevsner famously asserted that 'a bicycle shed is a building; Lincoln cathedral is architecture', ${ }^{46}$ architects and their historians have sought to elevate architecture above mere building. There is a process of selection artificial rather than natural - that enables a building to transcend into the realm of architecture. Publication has played such a dominant role in this process that some critics have argued that it is the publication rather than the building itself that should be considered the end product of an architect's endeavours. For example, Edwin Heathcote, architectural critic of London's Financial Times, argued that:

Architects are like novelists. They regard the most important thing in their careers as being published. Buildings are all very well, but they are somehow only truly complete when they have appeared in a glossy mag. ${ }^{47}$

And Carol Weeber claimed that buildings don't become architecture until they are written about. ${ }^{48}$ So how do publications in general, and magazines in particular, achieve this elevation?

In Architecture and its Interpretation, Juan Pablo Bonta described the steps involved in the construction of the architectural canon: buildings went from 'blindness' to 'pre-canonical responses' to 'authoritative interpretations' to collective 'canonical interpretations', defined as 'a cumulative result of many previous responses, distilled by repetition and reduced to the bare essentials'. ${ }^{49}$ Bonta added a fourth stage of 'dissemination', considered as the integration of the canon into institutions such as education and exhibitions, which ultimately reproduce it for future generations. This process loosely follows E.H. Carr's description of how events of the past are translated into history: first, they are proposed by a critic or historian of prominence, then seconded and sponsored, before a handful are chosen for canonisation while the rest disappear into (or remain in) insignificance. ${ }^{50}$ Publication in a magazine is one of the most prominent ways that this first step can be taken in architecture and it emphasises that selection involves people making decisions about which buildings should be included and how they are reviewed. Furthermore, the proposer's and seconder's authority, or what Pierre Bourdieu called 'cultural capital', is paramount: the more of it they have, the better chance the building has of entering the canon. In this way, architectural magazines and their editors act as gatekeepers, or instruments of validation for projects and architects.

It is no coincidence that Hélène Lipstadt, who wrote one of the first doctoral dissertations on an architectural magazine applied the theories of Bourdieu to the field of architecture. ${ }^{51}$ Examining the social history of the earliest art, architectural, and civil engineering publications in France, Lipstadt established a '"theoretical model of the architectural press" as a social institution' by basing its analysis on Bourdieu's sociology. She claimed that magazines 'acted as authorities of 
"distinction" for architects" 52 through the bestowal of symbolic power which subsequently distinguished architects from engineers. Lipstadt reconsidered architecture in terms of Bourdieu's ideas:

For Bourdieu, the ultimate author is not an individual creator, but the field itself. Not only does it create the creator, it creates our belief, or illusion, our faith in the creator's power to transubstantiate material objects into art and our and the public's belief in that object as one of art. ${ }^{53}$

The idea that it is 'the field itself' that defines architecture helps explain the 'belief in the game of architecture', what Bourdieu called 'the illusio, the interest, the investment, in both economic and psychological senses'. ${ }^{54}$

Thinking of architecture in this way invites us to consider it as a field in which its agents - including architectural magazines and their contributors - are in a constant struggle to assert themselves and define architecture. A reading of architecture through the theoretical framework of Bourdieu, then, demands less emphasis on individual architects and their works and more on the field - the cultural environment and context - as the creator itself. The struggles, or battles, that agents participate in to assert their authority and collect cultural capital underlies the development of the field over time. This is evidenced by the nature of cultural production itself: new movements and positions have to be fought for and held within a (battle)field with the term 'avant-garde' itself a metaphor derived from a military's advance guard. ${ }^{55}$

In the battle to define architecture, agents with greater cultural capital, such as architectural magazines and their editors, have the power to bestow cultural capital on architects, their ideas and projects; equally, if a new, small magazine is published by a well-known architect, cultural capital and legitimacy could flow the other way. The fact that an editor or publisher selects a project, whether written, photographed or drawn, from the mass of architectural production that exists, and then spends limited resources of page space and editors' and/or designers' time on the dissemination of the project, suggests that the project needs to be in some way extraordinary. What makes it out of the ordinary depends on the selection criteria, or the editorial policy of the magazine, which in turn depends on ideology, connections, and publishers' motivations. Considering architecture as a field, and the field itself as creator, expands the definition of what constitutes architecture beyond buildings: what matters is that those with authority in the field accept and legitimise a production as architecture, allowing us to view the architectural magazine (as much as architects and their buildings) as a constituent component of defining architecture, and also as a work of architecture in its own right.

\section{The magazine as a work of architecture}

The position developed by Higgott, Colomina, and Rattenbury - that architectural magazines are spaces of architectural production, as opposed to merely documents that represent and disseminate architecture - encourages us to consider them as architectural objects worthy of study in their own right. Magazines are more than just 
sources of information, transmitters of architectural knowledge, or mineable 'storehouses' for architectural history. ${ }^{56}$ Rather, they constitute little works of architecture in and of themselves. A magazine is not only an analogue for a building, but is itself a construction, a kind of 'paper architecture' in many senses. Architectural magazines provide a literal space for design speculation away from the exigencies and contingencies of the building site. Real-world building projects depend on a site, budget, and client for their production. The literal physical site of the magazine spread, on the other hand, allows relative autonomy from such concerns: most famously, the celebrated speculative work of the Archigram group exists only in the pages of its 'telegram' periodical and its transportation in both time and space continues to reinforce the group's significance within the discipline without the need to actually, inconveniently build anything. ${ }^{57}$ Jannière defers to El Lissitzky's concept of 'book space' to describe the spatio-temporality of architectural magazines ${ }^{58}$ and sociologist of technologies, Bruno Latour, recognises the ability of the printed page, through such simple devices as 'proximity and optical consistency', to bring together distant realities and hold them just 'inches apart when flattened out onto the same surface'. ${ }^{59}$ Historically it is the double-page spread that provides the spatial demarcation and physical locus for what Jannière has termed the 'juxtapositions and semantic collisions' of text and image in architectural magazines. ${ }^{60}$

We should also not forget that magazines are designed objects with a material presence and their making is a material practice that shares many affinities with architectural design practices, whether by hand or by computer. When Alison and Peter Smithson stated that '[a] book is like a small building for us', they recognised implicit similarities in the two endeavours and put as much, if not more, time and energy into the former as the latter - the main reason their legacy persists today. ${ }^{61}$ While it is true that books, when considered 'architectural projects', 62 have a great deal in common with buildings, magazines - which are a cheaper, more ephemeral, regular and dynamic medium - developed a special relationship with architecture throughout the twentieth century. As Latour notes, fixing ideas in printed form has a constructive and stabilising effect on them because, to forward an opposing view, one is required to 'write another book, have it printed and mobilise [a counter argument] with copper plates' ${ }^{63}$ Even in the age of digital publishing there are material costs to be accounted for: servers, databases, computer software and hardware, and telecommunication networks together make up a 'cloud' of very real, very material infrastructures.

Most architects don't actually build buildings, but they do define, describe, and represent them through drawings and models, media which have many uses from design development to planning and client approval to communication to third parties for pricing or construction. Some designs never get off the drawing board but, for those that do, once the building is finished, a series of photographs are taken to capture it (in its prime) for communication and dissemination to others (mainly architects). These representations are the direct products of architects' labour, and the resulting building, one might argue, an indirect by-product. Nevertheless, 
whether or not an actual building results, architecture is created: drawings, models, and photographs are mediations of the buildings they represent and are immediately and conveniently publishable content, requiring little translation.

Many of the skills and techniques used to effectively assemble a magazine whether printed or digital - are routinely taught in an architectural education. Historically it was rub-down transfer lettering, moveable type, manual drafting, the process camera, and film transparencies that occupied the shared domain between the magazine layout table and the architectural design studio. More recently, digital image-editing, digital typesetting, three-dimensional modelling and rendering, vector-based illustration, and other forms of Computer Aided Design (CAD) have become common across the two disciplines. Architectural magazines have this in common with art magazines of the 1960s and '70s which became a 'new site of artistic practice, functioning as an alternative exhibition space' as artists 'began to explore [the magazine] as a medium in its own right, creating works expressly for the mass-produced page'.64

\section{The material of the magazine}

A magazine is a material form and, in the case of print magazines, one that requires an understanding of paper stock and coatings, offset lithography, typesetting, imposition and layout, gathering and binding. Setting out and assembling an architectural magazine is a spatialising activity involving construction grids and the plan-form organisation of objects and elements within the site boundary described by the margins of double-page spread. The production of magazines, therefore, provides an ideal training ground for an aspiring architect and it is not surprising that so many notables have made their first contributions to architecture in magazines. ${ }^{65}$ This is precisely why the Architectural Association is as much a publishing house as it is a school of architecture - the two disciplines are so intimately related.

Just as in the field of art, throughout the twentieth century and continuing into more recent times, architectural magazines have tended to 'gather' groups around them, becoming projects around which to focus, negotiate, and consolidate a shared agenda and group agency. ${ }^{66}$ As Steven Heller has written, ' $[\mathrm{m}]$ lovements are formed around a core - an idea, ideal, or ideology and avant-garde publications serve as rallying points that reflect, through word and picture, the principles on which the respective movements are founded'. ${ }^{67}$ This tendency is as true for professional as avant-garde publications. Architectural theorists have drawn on Latour's notion of 'gathering' to account for the 'relational effects' of contemporary architectural technologies: ${ }^{68}$ publications 'gather' individuals into networks of production, distribution, and reception.

Gathering together editors, assistants, architects, firms, institutions, and clubs, architectural magazines contribute to the formation and stabilisation of the relational networks of architecture. Collectively-made and multiply-authored, magazines bring diverse groups together in their production - a condition that situates a magazine at the centre of a 'political universe'. ${ }^{69}$ Coincidentally, this term has an analogous use in modern binding and bibliography where a gathering is a 'single sheet, or several 
sheets of paper folded to form a single group of leaves in a book or other printed publication' ${ }^{70}$ Like a building project, magazines are born of collaboration. Although they may indeed be 'led by one guiding spirit', 71 it takes a multitude to bring a magazine into being and to keep it going. Furthermore, the low-tech, do-it-yourself opportunities of magazines and their ability to operate outside of the recognised 'establishment' publishing houses, means that the cost of magazine publication has historically been considerably lower than that for books, making them more egalitarian and accessible to groups on the fringes of architectural culture to contribute to the 'critical sphere'.

Architectural magazines establish this 'critical' or 'public sphere' in which a shared idea of architecture is constructed. As well as a material practice and social construction, architecture exists through its discursive formation, especially in the public realm. The periodical release of magazines creates a temporal space for the community of producers and readers to publicly 'construct' a shared idea of architecture. This occurs through something like Wittman's notion of a Habermasian critical public sphere, where it is likely that many people are reading the same thing at around the same time and between issues creating an architectural discourse, whether it be through lectures, 'crits', or chats in the pub. Magazines provide an opportunity for such a 'call-and-response' mechanism to occur across space and time and form of public reasoning and negotiation about what architecture is and should be. ${ }^{72}$ By containing many textual genres (such as reportage, reviews, building case studies, criticism, letters, editorials, miscellanea, photographs, drawings, adverts, polemic or technical features, and so on) and by being published periodically and including voices from multiple contributors, architectural magazines participate in an ongoing chain of utterances. As Mikhail Bakhtin explained, any text becomes part creation and part repetition: '[a]ny utterance is a link in a very complexly organized chain of other utterances'. ${ }^{73}$ Each text responds to previous ones, either from a previous issue of the same magazine, or from another magazine or book or lecture or exhibition, and in turn anticipates future texts. Its publication automatically enters it into the world of intertextuality for other future texts with which it 'builds on them, polemicizes with them, or simply presumes that they are already known to the listener'. ${ }^{74}$

The inherent and necessary polyphony and multimodality of magazines emerges precisely because they are created - visually, textually, and typographically by many different authors. Partly this is a function of the magazine genre itself which is distinguished by its diversity of content; and partly it relates to the variable semiotic competencies of the personas working together to make a magazine: editor, graphic designer, photographer, advertiser, art director, printer, contributing author, letter-writing subscriber, and so on participate in what linguists Gunther Kress and Theo van Leeuwen describe as the 'intricate division of labour of magazine production.' ${ }^{75}$ Magazines are construction sites and spaces of negotiation - small in scale but enormous in scope. Collaborative and conflictual, to succeed they must 
retain their complexity, multimodality, and polysemy while reconciling their contradictions into a coherent whole.

\section{Identifying and classifying architectural magazines}

While the criteria identified above distinguish magazines from other media texts, including from newspapers which have their own historical trajectory, ${ }_{1}^{76}$ it is also helpful to delineate subcategories within the medium. In a systematic literature review of magazine studies, Prior-Miller recognised the difficulties of categorising magazines, pointing out how diversely subcategories have been defined. She proposed the most effective way to classify magazines is by function, adopting terms that magazine makers and readers themselves use to describe their work. ${ }^{77}$ Adopting this kind of common-sense 'operational theory ${ }^{178}$ of media classification considers the language that media producers use on a daily basis: as media theorist Denis McQuail puts it, this is 'the kind of knowledge about the media [that] refers to the practical ideas assembled and applied by media practitioners in the conduct of their own media work' ${ }^{79}$

The terms that architects and producers of architectural magazines use to talk about their work, therefore, provide the most useful way of subcategorising magazines: not imposed as abstract entities but from the grounded discourses and shared understandings of magazine makers and readers. With this in mind and based on a survey of the 'architectural journalscape' that one of this paper's authors recently conducted for an architectural academic journal, ${ }^{80}$ we assemble architectural magazines into three general groups, each loosely related to one of the three facets of the field of architecture identified at the top of this paper: professional magazines, academic journals, and little magazines.

Professional magazines are essentially the 'trade press' that represent, and are mainly of interest to, the practice of architecture. With printed circulations in the tens of thousands, they are commercial operations (business-to-business) that are financially supported by some combination of an organisation (i.e. a 'members' magazine'), subscription, and advertising. Important British examples that continue today include the Architectural Review (est. 1896), The Architects' Journal (est. 1895 as The Builder's Journal), and Architecture Today (est. 1989). And Australian examples include Architecture Australia (est. 1904 as The Journal of the Institute of Architects of New South Wales), Architectural Review Asia Pacific (est. 1993), and the titles produced by the state chapters of the Australian Institute of Architects. Professional magazines are one of the primary validators of architecture, as described above and are therefore one of the most important and powerful institutions in the field of architecture.

We can therefore consider the architectural press as one of the institutions that supported the development of the architectural profession throughout the nineteenth century, alongside the schools, academies, societies, and institutes. In Europe, architectural periodicals emerged at the beginning of that century to support the establishment of a profession distinct from others such as surveyors, engineers 
and contractors who were interested in the construction industry. One of the ways of doing this, for example, was to educate the public in matters of taste. The Institute of British Architects was established in 1834 (becoming the RIBA with a royal charter three years later), and became the default learned society of the profession in Britain, and subsequently across what was then its Empire. It issued its Transactions irregularly from 1836 onwards, chronicling the Institute's proceedings, such as meetings, notices, reports and publishing transcriptions of its learned gentlemen's lectures. The Journal of the R.I.B.A., Third Series - what is now known as the RIBA Journal- first appeared in $1893 .{ }^{81}$ While the RIBA has continued to play the role of a learned society (albeit without an Empire), and its magazine (in the sense of a 'storehouse' of knowledge) is called a Journal, this periodical was, and continues to be, an example of a 'professional magazine'.

It wasn't until the twentieth century, and the emergence of modernist ideologies, that other types of architectural magazine started to appear in the form of 'little magazines'. This genre is closely associated with the avant-garde, which is possibly why it has been the focus of most research into architectural magazines to date. The term 'little magazine' was adopted from the early twentieth-century literary magazines 'that took as their mission the publication of art, literature, and social theory by progressive writers'. ${ }^{82}$ Little magazines have their own defining characteristics: they tend to be printed in limited runs; circulated to a select audience; feel no obligation to appear regularly; have a short life, and, as Denise Scott Brown observed, are 'led by one guiding spirit, trying to make one point, [...] are hand-made and usually ill-kempt in appearance, but with a certain flair'. ${ }^{83}$ They are published with little or no regard for commercial gain which means that the editors enjoy almost complete editorial freedom as they are not concerned about alienating advertisers. This editorial freedom often manifests itself in a particular ideological position or manifesto. In fact, they often define groups and movements: Jannière and Vanlaethem noted that studies on avant-garde magazines 'considered the magazine to be the backbone of pioneering movements: the public declaration of a manifesto position marked the birth of a group and ensured its cohesiveness, even its ideological coherence'. ${ }^{84}$

Architectural little magazines blossomed in three key periods which map onto moments of crisis in architecture: the 1920s, the 1960s, and the 2010s. After the First World War, with new avant-garde ideas of how to build a new world of modernity, a whole raft of daring modernist periodicals emerged, such as $G$ and Bauhaus in Germany, Sovremennaia Arkhitektura, Lef, and Veshch'in Russia, Wendingen and de Stijl in Holland, I'Esprit Nouveau in France and all the Futurist periodicals such as Lacerba and Noi in Italy. Each of these delivered a clear modernist message through a montage of bold unfussy design, photography, and typography. Colomina emphasised the importance of these early little magazines, and how the history of the avant-garde in art and architecture is intertwined with that of its publication, saying: 
Futurismo didn't exist before the publication of the manifesto in Le Figaro, in France Le Corbusier did not exist before l'Esprit Nouveau magazine in 19201925. It's not only that he became known as an architect and developed a clientèle through this magazine, the very name Le Corbusier did not exist before the publication. ${ }^{85}$

The next wave of avant-garde 'zines appeared in the 1960s due to a combination of cheaper and easier magazine production methods and a growing disillusionment with a modernism that had become mainstream. These are the 'zines that are featured in Clip/Stamp/Fold, the most celebrated of which were Utopie in France, Oppositions in the USA, Arquitectura Bis in Spain, and especially Archigram and post$1970 A D$ in the UK. Today, as society and architecture's place within it re-calibrates due to the economic crash of 2008 and the emerging dominance of digital technologies, we can see a third wave of 'zines, witnessed, for example, by Elias Redstone's curation of the travelling exhibition Archizines ${ }^{86}$ and Carlo Menon's PhD research at the Bartlett School of Architecture, UCL. ${ }^{87}$ Amongst these 'archizines' we would expect to find another sub-genre of architectural magazine, the 'fanzine', one of the most successful recent examples of which is the modernist, established in 2011 on a wave of nostalgia for Brutalist architecture in Britain. Written by enthusiasts, such magazines are necessarily only available in paper format, being a tactile object of design and becoming something of a collector's item. As business-to-consumer magazines that are financially precarious and not aimed at making a profit, little magazines, 'zines, and fanzines, form a fundamental facet of architectural culture as a site for architectural production in both form and content.

A third subcategory of architectural magazines - 'academic journals' such as the one this paper is published in - are those that are of interest to the academy in terms of architectural research and are distinguished from other architectural magazines by the process of formalised peer review. For C. Greig Crysler, academic journals are 'gatekeepers' limiting the boundaries of what it is possible to say and know in architecture. ${ }^{88}$ By focusing on the Journal of the Society of Architectural Historians, Assemblage, Traditional Dwellings and Settlements Review, International Journal of Urban and Regional Research, and Society and Space, Crysler was able to describe how, in the decades between 1960 and 2000, academic journals helped establish the limits of architecture's institutional knowledge.

British refereed scholarly journals did not really appear in architecture until the 1970s when architectural education migrated into universities on the recommendations of the 1958 Oxford Conference and subsequently developed into an academic discipline in its own right. One journal that emerged to support the resulting research was Architectural Research and Teaching $(A R T)$ which appeared in 1970. It became affiliated with the RIBA and merged with an editorial board from the American Institute of Architects to form the Journal of Architectural Research (JAR) in 1974. This international journal was concerned with research from the discipline of architecture specifically, was published three times a year, and its refereeing consisted of 'one or more of the editorial board work[ing] with the author on 
editorial preparation of the paper'. ${ }^{89}$ The $J A R$ ceased publication in 1980 but the introduction of the UK's Research Assessment Exercise in 1986, which started moving the funding of universities away from teaching to research in Britain, required new avenues to support the publication of architectural research. arq: Architectural Research Quarterly appeared in 1995, on the centenary of the Architects' Journal (according to its first editor Peter Carolin), ${ }^{90}$ and the RIBA's Journal of Architecture followed shortly after.

Elsewhere too, changes in university funding policies have resulted in an increasing requirement for academics - including in architecture departments - to cite, and be cited in, peer-reviewed academic journals. ${ }^{91}$ According to Ruth Neumann and James Guthrie, in Australia the "'marketization" and "performance measurement" of academic activities such as teaching and research' has seen university funding allocations directly linked to the publication of academic research in peer-reviewed journals. ${ }^{92}$ This measure, which has 'involved the collection and classification of publications', has been to a large degree responsible for the allocation and distribution of money to modern universities, as It has in Britain. ${ }^{93}$ As academic performance ratings and faculty funding became increasingly affected by publication of articles in peer-reviewed journals, there came a correlated pressure to find suitable publication avenues. ${ }^{94}$ The emergence in 1996 (again), of the peer-reviewed Architecture Theory Review out of the University of Sydney can be seen as one manifestation of this pressure.

The value of academic journals tends to be in their content rather than their format, so they have migrated almost completely online, and the circulation of printed issues today tends to be in the low hundreds. They also tend to be extremely profitable for publishers as due to the 'publish or perish' mantra of academia, content is provided completely gratis by authors who occasionally, in the case of Gold Open Access, even pay for the privilege of being published in them, such is the level of validation that publication confers.

Besides these three sub-categories of professional magazines, little magazines, and academic journals, it is possible to identify a fourth genre-shifting periodical that thrives in the flexible and shifting domain of their overlaps and intersections. In occupying this 'marginal'95 territory, they not only gather a great variety of content but combine different magazine genres into a hybrid medium. This is similar to how the editors of OASE described their 'Magazine of Neither', in 'a zone where arguments or ideas were put forward in the form of a magazine, often with academic connections, as a recognisable position or tendency, ideologically firm and often supported by graphic experiments [...] where various disciplinary focuses can interact. ${ }^{16}$ These hybrid titles tend to be closely linked to architecture schools: produced by and aimed at young architects, students, and practitioners who teach. Consisting of architectural research that hasn't necessarily been through a formal peer-review process, speculative theoretical texts, and unbuilt projects, examples today include Harvard Design Magazine (est. 1997), Yale's Perspecta (est. 1952), ${ }^{97} A A$ Files (est. 1981), OASE (est. 1981 at TU Delft), Princeton's Pidgin (est. 2005), Volume 
(est. 2005 by OMA and Columbia's Laboratory for Architectural Broadcasting), and $A D$ (est. 1930, little from 1970, hybrid from 1992). They often have institutional backing, offering financial and/or in-kind support and, very importantly, are produced in a way that takes advantage of free or cheap production labour from students or young academics or architects who need to be published (validated) to kickstart their careers. Hybrid magazines provide a critical space, insulated from the exigencies of practice and the financial pressures of attracting and retaining advertisers and this makes them a low-risk domain in which new ideas of what architecture is, can be constructed and contested. In hybrid magazines, designers and production staff can be enlisted from a cohort of talented architectural students, who because of a desire to establish capital of their own, and a capability to manipulate the design tools of the day because of their architectural training, represent a ready-made and perfectly specialised workforce.

Importantly, while the authority of an institutional backer does not allow hybrid magazines to be avant-garde in the manner of little magazines, hybrid magazines are incredibly diverse - textually, visually, typographically, and materially and this contributes to their efficacy as construction sites. An important characteristic of the magazine format generally, is its inclusivity to many different genres:

reportage, review, editorial, essay, advertisement, book-review, exegesis, visual essay, letter to the editor, manifesto, are assembled together and made coherent by the magazine form. The collection of these different genres, which are folded together textually and materially in magazines, also contributes to the formation of new genres, through a process linguists refer to as 'genre mixing'. ${ }^{98}$ Newly assembled genres provided new terms and new forms for talking about architecture and a mechanism for mapping ideas from other disciplines onto architectural objects and practices - this kind of transcoding was the explicit aim for the journal Assemblage ${ }^{99}$ and the ANY conferences and publications during the 1990s. ${ }^{100}$ Former Assemblage editor, K. Michael Hays, has described how that publication and its predecessor Oppositions, were participants in a single project: the first establishing a domain of disciplinary autonomy for architecture; and the second, challenging these boundaries by 'fold[ing] architecture into constructions of themes that were never part of Oppositions repertoire - subjectivity and gender, power and property, geopolitics, and others. ${ }^{101}$

It is this quality of being variable and difficult to pin down that makes a hybrid magazine a bridge, spanning between profession, academe, and discipline. As a flexible and shared object, capable of meaning different things to different people occupying different social realities, while offering the authority and validation of an institutional benefactor, a hybrid magazine provides a back-channel for ideas to translate between the different sub-fields of architecture: in and out of the academe; between profession and discipline; between avant-garde and routine; between metaphysics and wet-area detailing. The validation associated with the hybrid type is supported and enhanced by their institutional backing which confers authority and cultural capital. With printed circulations in the thousands - more than little 'zines 
and academic journals, but less than professional magazines - hybrids are particularly efficacious because they enrol a large and diverse network of influential actors and draw together these different domains of architecture. McLeod has recognised the global importance of institutions such as the AA and the IAUS, characterising them as 'international exchange centre[s]' for the distribution of architectural theory. ${ }^{102}$ The periodicals associated with these institutions are a crucial part of their success. Even without peer-review, hybrid architectural magazines rate highly as validators of architectural ideas and projects. Importantly, they tend to appear as print, rather than digital, publications - constructed objects with a material presence in the physical world.

\section{What does the medium of the architectural magazine say about architecture?}

We have suggested that a range of architectural media can be identified as magazines by virtue of the following criteria: periodical release; sustained identity over time; gathering a great variety of content communicated multimodally; and being directed at a particular interest group. Drawing on the emerging field of magazine studies and following Abrahamson, we also suggested that magazines have two characteristics that make them an exceptional type of media. Surveying the field of architectural publishing prompted us to add a third criterion: architectural magazines are sites of architectural production, specifically in the way that they validate the field of architecture and are architectural projects in their own right. These characteristics grant them their exceptionality compared to magazine publishing in other disciplines and are what make them 'architectural'. Finally, based on an understanding of categories of architectural publishing as being socially constructed, we defined three genres of contemporary architectural magazines. Doing so made it possible to reveal the presence of a fourth, hybrid genre situated at their intersection, which, in resisting classification, is particularly potent in the media construction of architecture.

In proposing an 'architectural magazine exceptionalism' and a special relationship with the periodical format, we argue that modern architecture wouldn't be architecture without the architectural magazine, similar to how Renaissance architecture could not have existed without the architectural treatise. ${ }^{103}$ Architectural magazines create a critical sphere in which people who have an interest in architecture negotiate ideas of what architecture is, could, or should be. Their multimodality and fluid hybridity; their affinity in production methods with the expertise of their readers; their physical, material, visual, and spatial design, together makes this the medium that most naturally captures architecture's inherent complexity and contradiction. This affinity makes the magazine uniquely able to present and represent modern architecture, reflecting and directing the field. This makes sense because we recognise architecture itself as a hybrid enterprise: a profession (practice), a discipline (academia), and a culture (art), and uniquely, all these things at once. Each of these overlapping sub-fields has cultivated a genre of 
magazine suited to its requirements while hybrid titles have emerged to accommodate the spaces in between this trinity.

Within the already exceptional field of architectural magazine publishing, we believe the hybrid magazine to be an 'exceptionally exceptional' object: an 'uber' architectural magazine, exemplifying the genre-bending heterogeneity of the architectural magazine in general. Because it is a physical and temporal space for criticality and conjecture about what architecture is, could, or should be, it is this hybrid type that exemplifies our idea of architectural magazine exceptionalism - they are the sites par excellence where architecture is made and found.

This then brings into focus the question of the future of the architectural magazine and especially what form the hybrid magazines of the future may take. The significance of the physicality of a hybrid magazine, and just how integral it is to its potency remains to be explored. It is, however, an observation that raises important questions about what media will fulfil this important role in a future increasingly dominated by digital publishing. The future directions of the hybrid magazines and the full effects of the digital turn on architectural magazines more generally is a terrain still to be explored. It is our hope that this paper provides a sound starting position and theoretical framework from which to begin that journey.

\section{References}

Abrahamson, David, 'Beyond the Mirror Metaphor: Magazine Exceptionalism and Sociocultural Change', Journal of Magazine and New Media Research, 4 (2002)

- - , 'Brilliant Fragments: The Scholarly Engagement with the American Magazine.', in The American Magazine: Research Perspectives and Prospects, ed. by David Abrahamson (Ames: lowa State University Press, 1995), pp. xvii-xxi

- - , 'Magazine Exceptionalism: The Concept, the Criteria, the Challenge', Journalism Studies, 8.4 (2007), 667-70 <https://doi.org/10.1080/14616700701412225>

Allen, Gwen, Artists' Magazines: An Alternative Space for Art (Cambridge, MA: MIT Press, 2011)

Bakhtin, Mikhail, Speech Genres and Other Late Essays (University of Texas Press, 1986)

Bonta, Juan Pablo, Architecture and Its Interpretation: A Study of Expressive Systems in Architecture (London: Lund Humphries, 1979)

Bourdieu, Pierre, The Field of Cultural Production: Essays on Art and Literature (Cambridge: Polity Press, 1993)

Buckley, Craig, and Jean-Louis Y. N. Violeau, - Utopie : Texts and Projects, 1967-1978

'Carlo Menon', The Bartlett School of Architecture, 2017 <https://www.ucl.ac.uk/bartlett/architecture/people/mphil-phd/carlo-menon> [accessed 24 April 2020]

Carolin, Peter. Letter to Stephen Parnell, 'ARQ Origins', 30 October 2013 
Carpo, Mario, Architecture in the Age of Printing: Orality, Writing, Typography, and Printed Images in the History of Architectural Theory (Cambridge, MA: MIT Press, 2001)

Carr, Edward H., What Is History? (London: Penguin Books, 1964)

Colomina, Beatriz, 'Little AD' (presented at the 80 Years of AD (1930-2010), R.I.B.A., London, 2010)

- - , Privacy and Publicity: Modern Architecture as Mass Media (Cambridge, Mass.: MIT Press, 1994)

Colomina, Beatriz, and Craig Buckley, eds., Clip, Stamp, Fold: The Radical Architecture of Little Magazines, 196X - 197X (New York: Actar, 2010)

-- , eds., Clip, Stamp, Fold: The Radical Architecture of Little Magazines, 196X - 197X (New York: Actar, 2010)

Colomina, Beatriz, Craig Buckley, and Urtzi Grau, Clip/Stamp/Fold: The Radical Architecture of Little Magazines, 196X to 197X, ed. by Beatriz Colomina, Craig Buckley, and Urtzi Grau (Barcelona, Spain: Actar, 2010)

Colomina, Beatriz, and Joan Ockman, eds., Architectureproduction (New York, NY: Princeton Architectural Press, 1988)

Crysler, C. Greig, Writing Spaces: Discourses of Architecture, Urbanism, and the Built Environment, 1960-2000 (New York: Routledge, 2003)

Crysler, C. Greig, Stephen Cairns, and Hilde Heynen, 'Architectural Theory in an Expanded Field', in The SAGE Handbook of Architectural Theory, ed. by C. Greig Crysler, Stephen Cairns, and Hilde Heynen (London: SAGE, 2012), pp. 1-21

Erten, Erdem, 'Shaping “The Second Half Century:" The Architectural Review, 1947-1971' (unpublished PhD, Massachusetts Institute of Technology, 2004)

Fairclough, Norman, Analysing Discourse: Textual Analysis for Social Research, 1st ed. (Routledge, 2003)

Fosdick, Scott, 'The State of Magazine Research in 2008', Journal of Magazine and New Media Research, 10.1 (2008), 1-4

Goad, Philip, 'One Hundred Years of Discourse: Architecture Australia 1904-2004', Architecture Australia, 93.1 (2004), 18-26

Gubler, Jacques, ABC: Architecttura e Avanguardia 1924-1928 (Milano: Electa, 1983)

- - , 'I Dispacci Dell'avanguardisa', Rassegna, December 1982, pp. 5-11

Habermas, Jürgen, The Structural Transformation of the Public Sphere: An Inquiry into a Category of Bourgeois Society, trans. by Thomas Burger (Cambridge: Polity, 1989)

Heathcote, Edwin, 'Foreword', in Is It All About Image?: How PR Works in Architecture, by Laura Iloniemi (London: John Wiley \& Sons, 2004), pp. 6-7 
Heller, Steven, Merz to Emigre and beyond: Avant-Garde Magazine Design of the Twentieth Century (London: Phaidon, 2003)

Heynen, Hilde, and Gwendolyn Wright, 'Introduction: Shifting Paradigms and Concerns', in The SAGE Handbook of Architectural Theory, ed. by C. Greig Crysler, Stephen Cairns, and Hilde Heynen (London: SAGE, 2012), pp. 41-55

Higgott, Andrew, Mediating Modernism: Architectural Cultures in Britain (London, 2007)

Hogben, Paul, and Stanislaus Fung, 'Reading Australian Architectural Journals as Historical Sources', Architectural Theory Review, 2.1 (1996), 15-29 <https://doi.org/10.1080/13264829609478301>

Holmes, Tim, 'MagBlog: Newspaper People *still* Don't Get Magazines', 2016 <https://timholmes.blogspot.com/2016/07/newspaper-people-still-dont-get.html> [accessed 21 April 2020]

Hsieh, Lisa L., 'Architext: The Readable, Playable and Edible Architecture of Japanese New Wave' (unpublished PhD, Princeton University, 2013)

Ibelings, Hans, 'A Parallel Universe', Wonderland, 2008, pp. 8-9

- - - Letter to Stephen Parnell, 'Carel Weeber', 6 March 2009

Jannière, Hélène, 'Juxtapositions and Semantic Collisions of Text and Image in Architectural Magazines of the 1920s and 1930s' (presented at the Investigating and Writing Architectural History: Subjects, Methodologies and Frontiers: Papers from the Third EAHN International Meeting, Turin, 2014)

- - , 'La Critique Architecturale a La Recherche de Ses Instruments: L'Architecture d'Aujourd'hui et Architecture Mouvement Continuite, 1960-1974', in Architectural Periodicals in the 1960s and 1970s: Towards a Factual, Intellectual and Material History, ed. by Hélène Jannière, Alexis Sornin, and France Vanlaethem, trans. by author's translation, Architectural Periodicals in the 1960s and 1970s: Towards a Factual, Intellectual and Material History, 2008, pp. 271-94

Jannière, Hélène, Alexis Sornin, and France Vanlaethem, Revues d'architecture Dans Les Annees 1960 et 1970: Fragments d'une Histoire Événementielle, Intellectuelle et Matérielle ; Actes Du Colloque International Tenu Les 6 et 7 Mai 2004 Au Centre Canadien d'Architecture (CCA) à Montréal = Architectural Periodicals in the 1960s and 1970s: Towards a Factual, Intellectual and Material History (Montreal: Institut de recherche en histoire de l'architecture (IRHA), 2008)

Jannière, Hélène, and France Vanlaethem, 'Architectural Magazines as Historical Source or Object? A Methodological Essay', in Architectural Periodicals in the 1960s and 1970s: Towards a Factual, Intellectual and Material History, ed. by Hélène Jannière, Alexis Sornin, and France Vanlaethem (Canada: Institut de recherche en histoire de l'architecture, 2008), pp. 41-68

Jenkins, Frank, 'Nineteenth Century Periodicals', in Concerning Architecture: Essays on Architectural Writers and Writing Presented to Nikolaus Pevsner, ed. by Summerson, John (London: Allen Lane, 1968) 
K. Michael Hays, 'The Oppositions of Autonomy and History', in Oppositions Reader: Selected Readings from a Journal for Ideas and Criticism in Architecture, 1973-1984, ed. by K. Michael Hays (New York: Princeton Architectural Press, 1998), pp. ix-xv

Kallipoliti, Lydia, 'Mission Galactic Household: The Resurgence of Cosmological Imagination in the Architecture of the 1960s and 1970s' (unpublished PhD, Princeton University, 2013)

Kitch, Carolyn, 'Theory and Method Analysis: Models for Understanding Magazines', in The Routledge Handbook of Magazine Research: The Future of the Magazine Form, ed. by David Abrahamson and Marcia Prior-Miller, 2015, pp. 9-21

Kress, Gunther R., and Theo van Leeuwen, Multimodal Discourse: The Modes and Media of Contemporary Communication (London; New York: Arnold; Oxford University Press, 2001)

Latour, Bruno, 'Drawing Things Together', in Representations in Scientific Practice, ed. by Michael Lynch and Steven Woolgar (Cambridge Mass.: MIT Press, 1990), pp. 19-68

Law, John, Aircraft Stories: Decentring the Object in Technoscience (London: Duke University Press, 2002)

Lemoine, Bertrand, and Hélène Lipstadt, Catalogue Raisonné Des Revues d'architecture et de Construction En France, 1800-1914 (Paris: Centre d'Études et de Documentation sur I'Architecture Métallique, 1985)

Lipstadt, Hélène, 'Pour Une Histoire Sociale de La Presse Architecturale: La Revue Générale de I'Architecture et César Daly (1840-1888)' (unpublished Ph.D. Dissertation, École des Hautes Études en Sciences Sociales, 1979)

- - , 'Sociology: Bourdieu's Bequest', Journal of the Society of Architectural Historians, 64.4 (2005), pp. 433-436

McLeod, Mary, 'Architecture and Politics in the Reagan Era: From Postmodernism to Deconstructivism', Assemblage, 8, 1989, 23-59 <https://doi.org/10.2307/3171013>

McLuhan, Marshall, The Medium Is the Massage (London: Penguin, 2008)

McQuail, Denis, McQuail's Mass Communication Theory, 4th ed (London ; Thousand Oaks: Sage Publications, 2000)

Moreno, Joaquim, '“Arquitecturas Bis" (1974--1985): From Publication to Public Action' (unpublished PhD, Princeton University, 2011)

Neumann, Ruth, and James Guthrie, 'The Corporatization of Research in Australian Higher Education', Critical Perspectives on Accounting, 13.5-6 (2002), 721-41 <https://doi.org/10.1006/cpac.2002.0557>

Neumann, Ruth, and Alan Lindsay, 'Excellence at Risk?: The Future of Research and Research Training in Australian Universities', The Australian Quarterly, 59.2 (1987), 199-209 $<$ https://doi.org/10.2307/20635432>

- - , 'Research Policy and the Changing Nature of Australia's Universities', Higher Education, 17.3 (1988), 307-21 
'Notes to Contributors', Journal of Architectural Research, 7.3 (1980), 8-9

Parnell, Steve, 'Architectural Design, 1954-1972: The Contribution of the Architectural Magazine to the Writing of Architectural History' (unpublished PhD Dissertation, University of Sheffield, 2012)

- - , 'Architecture Magazines: Playgrounds and Battlegrounds', in Common Ground: A Critical Reader, ed. by Kieran Long and Shumi Bose (Venezia: Marsilio, 2012), pp. 305-8

- - , 'The Journal of Architecture in the Context of Contemporary Academic Publishing', unpublished report for The Journal of Architecture, November 2013

Patteeuw, Véronique, 'Architecture, Writing And Criticism In The 1960s And 1970s', Architectural Theory Review, 15.3 (2010), 281-97 <https://doi.org/10.1080/13264826.2010.524309>

Pevsner, Nikolaus, An Outline of European Architecture (London: Penguin Books, 1942)

Prior-Miller, Marcia R., 'Magazine Typology: Using Operational Classification Theory', in The Routledge Handbook of Magazine Research: The Future of the Magazine Form, ed. by David Abrahamson and Marcia R. Prior-Miller (New York: Routledge, 2015), pp. 22-50

Rattenbury, Kester, This Is Not Architecture: Media Constructions (Florence: Taylor and Francis, 2005)

Sawyer, Mark, 'A Cloud of Things | A Network of Texts: Form, Content, Politics and Meaning in an Australian Architectural Periodical' (unpublished Ph.D. Dissertation, University of Western Australia, 2017)

- - , 'Call-and-Response: Group Formation and Agency Enacted through an Architectural Magazine, Its Letters and Editorials', ed. by Paul Hogben and Judith O'Callaghan (presented at the Society of Architectural Historians, Australia and New Zealand 2015: Architecture, Institutions and Change, Sydney: SAHANZ, 2015), pp. 548-57

- - , 'The Transition Translations: Marginality, Vagueness and Egalitarianism as Characteristics of an Australian Architectural Periodical', Journal of Magazine Media, 20.1-2 (In Press)

Schoonderbeek, Marc, Filip Geerts, Véronique Patteeuw, and Joachim Declerck, 'A Magazine of Neither. Twenty-Five Years of OASE', OASE, 75, 2008, 2-7

Schwarzer, Mitchell, 'History and Theory in Architectural Periodicals: Assembling Oppositions', Journal of the Society of Architectural Historians, 58.3 (1999), 342-48

<https://doi.org/10.2307/991527>

Scott Brown, Denise, 'Little Magazines in Architecture and Urbanism', Journal of the American Institute of Planners, 34.4 (1968), 223-33 <https://doi.org/10.1080/01944366808977811>

Seligmann, Ari, '(M)ANY Disciplinary Approaches', Architecture and Culture, 1.1 (2013), 68-95 <https://doi.org/10.2752/175145213X13756908698568>

Smithson, Alison, and Kester Rattenbury, 'Think of It as a Farm! Exhibitions, Books, Buildings: An Interview with Peter Smithson', in This Is Not Architecture: Media Constructions, ed. by Kester Rattenbury (London: Routledge, 2002), pp. 91-98 
Stern, Robert, Peggy Deamer, and Alan Plattus, Re-Reading Perspecta: The First Fifty Years of the Yale Architectural Journal (Cambridge, Mass.: MIT Press, 2004)

Tavares, André, The Anatomy of the Architectural Book (Zürich; Montreal: Lars Müller Publishers; Canadian Centre for Architecture, 2016)

Taylor-Hochberg, Amelia, 'Inside Pamphlet: How One of the Most Enduring Experimental Architecture Publications Got Its Start', Archinect, 2016 $<$ https://archinect.com/features/article/147814975/inside-pamphlet-how-one-of-the-mostenduring-experimental-architecture-publications-got-its-start> [accessed 22 April 2020]

Travers, David, Arts \& Architecture, 1945-1954: The Complete Reprint (Köln; Los Angeles: Taschen, 2008)

Trudgeon, Michael, 'Fast Forward Cassette Magazine (1978-1982)', RMIT Design Archive Journal, 3.2 (2013), 8-9

Watson, Nadia, 'The Whites vs the Grays: Re-Examining the 1970s Avant-Garde', The Journal of the Society of Architectural Historians, Australia and New Zealand, 15.1 (2005), 55-69 <https://doi.org/10.1080/10331867.2005.10525203>

Wittman, Richard, Architecture, Print Culture and the Public Sphere in Eighteenth-Century France (New York; London: Routledge, 2007)

Wolseley, Roland, Understanding Magazines, Second Edition (Ames, lowa: lowa State University Press, 1972)

\section{Acknowledgements}

arq gratefully acknowledges:

\section{Authors' addresses}

Stephen Parnell

stephen.parnell@ncl.ac.uk

\section{Mark Sawyer}

mark.sawyer@utas.edu.au

\section{Authors' biographies}

Stephen Parnell is an architect, architectural critic, and senior lecturer in Architecture at Newcastle University whose research and practice is in architectural magazines.

Mark Sawyer is a lecturer in Architecture and Design at the University of Tasmania where he teaches and researches on the intersection of architecture, design, and the media.

\section{PULL QUOTES}


'Architectural magazines have a special relationship with the profession [...] as unique and complicated and gloriously unpin-downable as architecture itself'.

'Magazines [...] act not only as reflectors, but also directors of a particular field of interest'.

'[...] the architectural magazine has been instrumental - central even - to creating a space for the production of architecture'.

'[...] architectural magazines and their editors act as gatekeepers, or instruments of validation for projects and architects'.

'[...] agents with greater cultural capital, such as architectural magazines and their editors, have the power to bestow cultural capital on architects [...]'.

'We should not forget that magazines are designed objects with a material presence $[\ldots]^{\prime}$.

'[...] architectural magazines have tended to 'gather' groups around them, becoming projects around which to focus, negotiate, and consolidate a shared agenda and group agency'.

'Architectural magazines establish a 'critical' or 'public sphere' in which a shared idea of architecture is constructed.'

'[...] the most effective way to classify magazines is by function $[\ldots]$ '.

'[...] the architectural press [was] one of the institutions that supported the development of the architectural profession [...].'

'[...] little magazines, zines, and fanzines form a fundamental facet of architectural culture $[\ldots]^{\prime}$.

'The value of academic journals tends to be in their content rather than their format [...].'

'An important characteristic of the magazine format [...] is its inclusivity to many different genres'.

'[...] a hybrid magazine provides a back-channel for ideas to translate between the different sub-fields of architecture [...]'.

'[...] we argue that modern architecture wouldn't be architecture without the architectural magazine, similar to how Renaissance architecture could not have existed without the architectural treatise'. 


\section{WEB ABSTRACT}

This paper develops a theoretical framework for the relationship between the architectural magazine and architecture, understood as a profession, a discipline, and a culture. By developing David Abrahamson's idea of 'magazine exceptionalism' from the field of magazines studies, it offers a definition of what constitutes an architectural magazine, arguing that to be architectural, a magazine must be a site of architectural production, as either a validator in the field of architecture or as an architectural project in its own right.

Developing the concept of 'architectural magazine exceptionalism' through an analysis of the 'architectural journalscape', we reflect on the medium's special relationship with architecture to argue that the architectural magazine is a fundamental component of modern architecture. We identify three sub-genres of architecture magazine, corresponding to architecture's sub-fields - profession, discipline, and culture - and a fourth, hybrid genre intersecting the other three which exemplifies architecture's complexity and contradiction. The paper concludes by extending Beatriz Colomina's claim that 'modern architecture only becomes modern with its engagement with the media', arguing that modern architecture simply would not be architecture without the architectural magazine. This conclusion recommends that the medium itself should be considered a crucial subject for architectural research. 
1. In this paper we use the term 'architecture' sociologically, to refer to the profession, discipline and culture of architecture - the practice, the academy, and the art - which we might collectively call the 'field of architecture', rather than the resulting material products, its buildings.

2. For instance, Joaquim Moreno, '"Arquitecturas Bis" (1974-1985): From Publication to Public Action' (unpublished PhD, Princeton University, 2011); Lisa L. Hsieh, 'Architext: The Readable, Playable and Edible Architecture of Japanese New Wave' (unpublished PhD, Princeton University, 2013); Lydia Kallipoliti, 'Mission Galactic Household: The Resurgence of Cosmological Imagination in the Architecture of the 1960s and 1970s' (unpublished PhD, Princeton University, 2013); Erdem Erten, 'Shaping "The Second Half Century:" The Architectural Review, 1947-1971' (unpublished PhD, Massachusetts Institute of Technology, 2004). Steve Parnell, 'Architectural Design, 1954-1972: The Contribution of the Architectural Magazine to the Writing of Architectural History' (unpublished PhD Dissertation, University of Sheffield, 2012); Mark Sawyer, 'A Cloud of Things | A Network of Texts: Form, Content, Politics and Meaning in an Australian Architectural Periodical' (unpublished PhD Dissertation, University of Western Australia, 2017).

3. For instance, 'The Site of Discourse: Thinking Architecture Through Publication', Lisbon, 2015; and, the paper session 'Launching the Architectural Magazine: The formation of a Genre', at the European Architectural History Network (EAHN) conference, Tallinn, 2018.

4. For instance, Robert Stern, Peggy Deamer, and Alan Plattus, Re-Reading Perspecta: The First Fifty Years of the Yale Architectural Journal (Cambridge MA: MIT Press, 2004); David Travers, Arts \& Architecture, 1945-1954: The Complete Reprint (Köln; Los Angeles: Taschen, 2008); Jacques Gubler, ABC: Architecttura e Avanguardia 19241928 (Milano: Electa, 1983); Craig Buckley and Jean-Louis Y. N. Violeau, Utopie: Texts and Projects, 1967-1978.

5. Hélène Jannière, Alexis Sornin, and France Vanlaethem, Revues d'architecture Dans Les Annees 1960 et 1970: Fragments d'une Histoire Événementielle, Intellectuelle et Matérielle; Actes Du Colloque International Tenu Les 6 et 7 Mai 2004 Au Centre Canadien d'Architecture (CCA) à Montréal = Architectural Periodicals in the 1960s and 1970s: Towards a Factual, Intellectual and Material History (Montreal: Institut de recherche en histoire de l'architecture (IRHA), 2008); Beatriz Colomina, Craig Buckley, and Urtzi Grau, Clip/Stamp/Fold: The Radical Architecture of Little Magazines, 196X to $197 X$, ed. by Beatriz Colomina, Craig Buckley, and Urtzi Grau (Barcelona, Spain: Actar, 2010).

6. Véronique Patteeuw, 'Architecture, Writing And Criticism In The 1960s And 1970s', Architectural Theory Review, 15.3 (2010), 281 - 97 (p. 291) <https://doi.org/10.1080/13264826.2010.524309>.

7. Denise Scott Brown, 'Little Magazines in Architecture and Urbanism', Journal of the American Institute of Planners, 34.4 (1968), 223 - 33 <https://doi.org/10.1080/01944366808977811>. 
8. Hilde Heynen and Gwendolyn Wright, 'Introduction: Shifting Paradigms and Concerns', in The SAGE Handbook of Architectural Theory, ed. by C. Greig Crysler, Stephen Cairns, and Hilde Heynen (London: SAGE, 2012), pp. 41 - 55 (p. 42); Mitchell Schwarzer, 'History and Theory in Architectural Periodicals: Assembling Oppositions', Journal of the Society of Architectural Historians, 58.3 (1999), 342 - 48 (p. 343) <https://doi.org/10.2307/991527>.

9. Hélène Jannière, 'La Critique Architecturale a La Recherche de Ses Instruments: L'Architecture d'Aujourd'hui et Architecture Mouvement Continuite, 1960-1974', in Architectural Periodicals in the 1960s and 1970s, ed. by Jannière, Sornin, and Vanlaethem, pp. $271-94$.

10. Mark Sawyer, 'Call-and-Response: Group Formation and Agency Enacted through an Architectural Magazine, Its Letters and Editorials', ed. by Paul Hogben and Judith O'Callaghan (presented at the Society of Architectural Historians, Australia and New Zealand 2015: Architecture, Institutions and Change, Sydney: SAHANZ, 2015), pp. 548 $-57$.

11. Paul Hogben and Stanislaus Fung, 'Reading Australian Architectural Journals as Historical Sources', Architectural Theory Review, 2.1 (1996), 15 - 29 $<$ https://doi.org/10.1080/13264829609478301>.

12. Philip Goad, 'One Hundred Years of Discourse: Architecture Australia 1904-2004', Architecture Australia, 93.1 (2004), 18 - 26 (p. 19).

13. Organised by the Institut de Recherche en Histoire de l'Architecture (IHRA), at the Canadian Centre for Architecture (CCA), Montréal, 6-7 May 2004.

14. Hélène Jannière and France Vanlaethem, 'Architectural Magazines as Historical Source or Object? A Methodological Essay', in Architectural Periodicals in the 1960 s and 1970s, ed. by Jannière, Sornin, and Vanlaethem, pp. $41-68$.

15. For instance, David Abrahamson, 'Brilliant Fragments: The Scholarly Engagement with the American Magazine', in The American Magazine: Research Perspectives and Prospects, ed. by David Abrahamson (Ames: lowa State University Press, 1995), pp. xvii - xxi; Scott Fosdick, 'The State of Magazine Research in 2008', Journal of Magazine and New Media Research, 10.1 (2008), 1 - 4.

16. Patteeuw, 'Architecture, Writing and Criticism', p. 286.

17. Marcia R. Prior-Miller, 'Magazine Typology: Using Operational Classification Theory', in The Routledge Handbook of Magazine Research: The Future of the Magazine Form, ed. by David Abrahamson and Marcia R. Prior-Miller (New York: Routledge, 2015), pp. $22-50$ (p. 23).

18. Marshall McLuhan, The Medium Is the Massage (London: Penguin, 2008).

19. Roland Wolseley, Understanding Magazines, 2nd edn (Ames: lowa State University Press, 1972), p. 7.

20. Prior-Miller, p. 23.

21. Wolseley, Roland, pp. $5-6$.

22. Gunther R. Kress and Theo van Leeuwen, Multimodal Discourse: The Modes and Media of Contemporary Communication (London: Arnold; Oxford University Press, 2001), p. 1,3. 
23. Tim Holmes, 'MagBlog: Newspaper People *still* Don't Get Magazines', 2016 <https://timholmes.blogspot.com/2016/07/newspaper-people-still-dont-get.html> [accessed 21 April 2020].

24. For instance, Michael Trudgeon, 'Fast Forward Cassette Magazine (1978-1982)', RMIT Design Archive Journal, 3.2 (2013), 8 - 9.

25. David Abrahamson, 'Magazine Exceptionalism: The Concept, the Criteria, the Challenge', Journalism Studies, 8.4 (2007), 667 - 70

<https://doi.org/10.1080/14616700701412225>.

26. Abrahamson, 'Magazine Exceptionalism'.

27. Ibid., p. 670.

28. See, Kitch, 'Theory and Method', p. 12.

29. Abrahamson, 'Magazine Exceptionalism', p. 670.

30. Ibid., p. 668.

31. David Abrahamson, 'Beyond the Mirror Metaphor: Magazine Exceptionalism and Sociocultural Change', Journal of Magazine and New Media Research, 4 (2002); Kitch. 32. Jürgen Habermas, The Structural Transformation of the Public Sphere: An Inquiry into a Category of Bourgeois Society, trans. by Thomas Burger (Cambridge: Polity, 1989), p. 24.

33. Jannière and Vanlaethem, 'Architectural Magazines', p. 42.

34. Clip/Stamp/Fold, ed. by Colomina and Buckley, p. 8.

35. Steve Parnell, 'Architecture Magazines: Playgrounds and Battlegrounds', in Common Ground: A Critical Reader, ed. by Kieran Long and Shumi Bose (Venezia: Marsilio, 2012), pp. $305-08$.

36. Habermas, p. 24.

37. Richard Wittman, Architecture, Print Culture and the Public Sphere in EighteenthCentury France (New York; London: Routledge, 2007), p. 6.

38. Wittman, p. 13.

39. Wittman, p. 6; Habermas, p. xv.

40. Habermas refers to it elsewhere as a 'critical sphere', see Habermas, p. 24.

41. See the papers collected in 'Architectural Magazines in the Nineteenth Century' ed. by Anne Hultzsch, special issue of The Journal of Architecture, 25.7 (2020).

42. Andrew Higgott, Mediating Modernism: Architectural Cultures in Britain (London, 2007), p. 7.

43. Beatriz Colomina, Privacy and Publicity: Modern Architecture as Mass Media (Cambridge MA: MIT Press, 1994), p. 14.

44. Beatriz Colomina and Joan Ockman (eds), Architectureproduction (New York, NY: Princeton Architectural Press, 1988), p. 7.

45. Kester Rattenbury, This Is Not Architecture: Media Constructions (Florence: Taylor and Francis, 2005), p. xxii.

46. Nikolaus Pevsner, An Outline of European Architecture (London: Penguin Books, 1942), p. 15. 
47. Edwin Heathcote, 'Foreword', in Is It All About Image?: How PR Works in Architecture, ed. by Laura Iloniemi (London: John Wiley \& Sons, 2004), pp. 6 - 7 (p. 6).

48. Cited in Hans Ibelings, 'A Parallel Universe', Wonderland, 2008, pp. 8 - 9; Ibelings confirmed that Weeber said this at a panel discussion in an email to Stephen Parnell, 6 March 2009.

49. Juan Pablo Bonta, Architecture and Its Interpretation: A Study of Expressive Systems in Architecture (London: Lund Humphries, 1979), p. 145.

50. These lectures were first published as Edward H. Carr, What Is History? (London: Penguin Books, 1964), a book that is still in print today.

51. Hélène Lipstadt, 'Pour Une Histoire Sociale de La Presse Architecturale: La Revue Générale de I'Architecture et César Daly (1840-1888)' (PhD Dissertation, École des Hautes Études en Sciences Sociales, 1979) published as Bertrand Lemoine and Hélène Lipstadt, Catalogue Raisonné Des Revues d'architecture et de Construction En France, 1800-1914 (Paris: Centre d'Études et de Documentation sur l'Architecture Métallique, 1985).

52. Jannière and Vanlaethem, 'Architectural Magazines', pp. 41 - 68 (p. 48).

53. Hélène Lipstadt, 'Sociology: Bourdieu's Bequest', Journal of the Society of Architectural Historians, 64.4 (2005), 433-36 (p. 434).

54. Pierre Bourdieu, The Field of Cultural Production: Essays on Art and Literature (Cambridge: Polity Press, 1993), p. 159.

55. Jacques Gubler, 'I Dispacci Dell'avanguardisa', Rassegna, December 1982, pp. 5 11 (р. 6).

56. The term 'magazine' is derived from the French 'magasin', or 'storehouse'. See, Jannière and Vanlaethem, 'Architectural Magazines', p. 14.

57. See, http://archigram.westminster.ac.uk/ [accessed April 13, 2020].

58. Hélène Jannière, 'Juxtapositions and Semantic Collisions of Text and Image in Architectural Magazines of the 1920s and 1930s' (presented at the Investigating and Writing Architectural History: Subjects, Methodologies and Frontiers: Papers from the Third EAHN International Meeting, Turin, 2014), p. 248.

59. Bruno Latour, 'Drawing Things Together', in Representations in Scientific Practice, ed. by Michael Lynch and Steven Woolgar (Cambridge MA: MIT Press, 1990), pp. 19 68 (p. 54).

60. Jannière, 'Juxtapositions'.

61. Alison Smithson and Kester Rattenbury, 'Think of It as a Farm! Exhibitions, Books, Buildings: An Interview with Peter Smithson', in This Is Not Architecture, ed. by Rattenbury, pp. 91 - 98 (p. 97).

62. André Tavares, The Anatomy of the Architectural Book (Zürich; Montreal: Lars Müller Publishers; Canadian Centre for Architecture, 2016), pp. 9 - 19; Wittman, pp. 1 -4 .

63. Latour, p. 34.

64. Gwen Allen, Artists' Magazines: An Alternative Space for Art (Cambridge MA: MIT Press, 2011), p. 1. 
65. For example, Steven Holl's enduring Pamphlet Architecture series which he started with bookseller William Stout in 1978 as he was starting out in architectural practice. See, Amelia Taylor-Hochberg, 'Inside Pamphlet: How One of the Most Enduring Experimental Architecture Publications Got Its Start', Archinect, 2016 $<$ https://archinect.com/features/article/147814975/inside-pamphlet-how-one-ofthe-most-enduring-experimental-architecture-publications-got-its-start> [accessed 22 April 2020].

66. For instance, Nadia Watson, 'The Whites vs the Grays: Re-Examining the 1970s Avant-Garde', Journal of the Society of Architectural Historians, Australia and New Zealand, 15.1 (2005), 55 - 69 <https://doi.org/10.1080/10331867.2005.10525203>. 67. Steven Heller, Merz to Emigre and beyond: Avant-Garde Magazine Design of the Twentieth Century (London: Phaidon, 2003), p. 6.

68. C. Greig Crysler, Stephen Cairns, and Hilde Heynen, 'Architectural Theory in an Expanded Field', in The SAGE Handbook of Architectural Theory, ed. by C. Greig Crysler, Stephen Cairns, and Hilde Heynen (London: SAGE, 2012), pp. $1-21$ (p. 13). 69. John Law, Aircraft Stories: Decentring the Object in Technoscience (London: Duke University Press, 2002), p. 153.

70. Joan M. Reitz, 'Gathering,' Online Dictionary for Library and Information Science, <http://www.abc-clio.com/ODLIS/odlis_s.aspx> [accessed 05 May 2020].

71. Scott Brown, p. 223.

72. Sawyer, 'Call-and-Response'.

73. Mikhail Bakhtin, Speech Genres and Other Late Essays (University of Texas Press, 1986), p. 69.

74. Bakhtin, p. 69.

75. Kress and van Leeuwen, p. 18.

76. Wolseley, Roland, pp. $5-6$.

77. Prior-Miller, p. 23.

78. Prior-Miller, p. 23.

79. Denis McQuail, McQuail's Mass Communication Theory, 4th edn (London; Thousand Oaks: Sage Publications, 2000), p. 8.

80. Steve Parnell, 'The Journal of Architecture in the Context of Contemporary Academic Publishing', unpublished report for The Journal of Architecture, November 2013.

81. Jenkins, Frank, 'Nineteenth Century Periodicals', in Concerning Architecture: Essays on Architectural Writers and Writing Presented to Nikolaus Pevsner, ed. by John Summerson (London: Allen Lane, 1968), pp. 153-60 (p. 156).

82. Clip/Stamp/Fold, ed. by Colomina and Buckley, p. 8.

83. Scott Brown, p. 223.

84. Jannière and Vanlaethem, 'Architectural Magazines', p. 49.

85. Beatriz Colomina, 'Little AD' (presented at the 80 Years of AD (1930-2010), RIBA, London, 2010) [emphasis added].

86. See <http://www.archizines.com> [accessed 26 October 2020]. 
87. 'Carlo Menon', The Bartlett School of Architecture, 2017

<https://www.ucl.ac.uk/bartlett/architecture/people/mphil-phd/carlo-menon> [accessed 24 April 2020].

88. C. Greig Crysler, Writing Spaces: Discourses of Architecture, Urbanism, and the Built Environment, 1960-2000 (New York: Routledge, 2003), p. 11.

89. 'Notes to Contributors', Journal of Architectural Research, 7.3 (1980), 8 - 9 (p. 8).

90. Email from Peter Carolin to Stephen Parnell, 'ARQ Origins', 30 October 2013.

91. Ruth Neumann and Alan Lindsay, 'Research Policy and the Changing Nature of Australia's Universities', Higher Education, 17.3 (1988), 307 - 21 (p. 310).

92. Ruth Neumann and James Guthrie, 'The Corporatization of Research in Australian Higher Education', Critical Perspectives on Accounting, 13.5 - 6 (2002), 721 - 41 $<$ https://doi.org/10.1006/cpac.2002.0557>.

93. Neumann and Guthrie, p. 729.

94. See, Neumann and Guthrie; Ruth Neumann and Alan Lindsay, 'Excellence at Risk?: The Future of Research and Research Training in Australian Universities', The Australian Quarterly, 59.2 (1987), 199 - 209 <https://doi.org/10.2307/20635432>; Neumann and Lindsay, 'Research Policy and the Changing Nature of Australia's Universities'.

95. Mark Sawyer, 'The Transition Translations: Marginality, Vagueness and Egalitarianism as Characteristics of an Australian Architectural Periodical', Journal of Magazine Media, 20.1 - 2 (In Press).

96. Marc Schoonderbeek and others, 'A Magazine of Neither. Twenty-Five Years of OASE', OASE, 75, 2008, 2-7 (p. 4).

97. Stern, Deamer, and Plattus.

98. Norman Fairclough, Analysing Discourse: Textual Analysis for Social Research (Routledge, 2003), p. 216.

99. Crysler, p. 195.

100. Ari Seligmann, '(M)ANY Disciplinary Approaches', Architecture and Culture, 1.1 (2013), 68 - 95 (p. 69) <https://doi.org/10.2752/175145213X13756908698568>. 101. K. Michael Hays, 'The Oppositions of Autonomy and History', in Oppositions Reader: Selected Readings from a Journal for Ideas and Criticism in Architecture, 1973-1984, ed. by K. Michael Hays (New York: Princeton Architectural Press, 1998), pp. ix - xv (p. xiv).

102. Mary McLeod, 'Architecture and Politics in the Reagan Era: From Postmodernism to Deconstructivism', Assemblage, 8, 1989, 23 - 59 (p. 44)

$<$ https://doi.org/10.2307/3171013>.

103. For the relationship between the architectural treatise and the Renaissance project, see, Mario Carpo, Architecture in the Age of Printing: Orality, Writing, Typography, and Printed Images in the History of Architectural Theory (Cambridge, MA: MIT Press, 2001). 